\title{
Bacterial expression and isotope labeling of AIMP1/p43 codosome protein for structural studies by multidimensional NMR spectroscopy
}

\author{
N. V. Vorobyova ${ }^{1,2}$, D. M. Lozhko', I. Yu. Zhukov ${ }^{3,4}$, A. I. Kornelyuk ${ }^{1,2}$ \\ ${ }^{1}$ Institute of Molecular Biology and Genetics, NAS of Ukraine \\ 150, Akademika Zabolotnoho Str., Kyiv, Ukraine, 03680 \\ ${ }^{2}$ Institute of High Technologies, \\ Taras Shevchenko National University of Kyiv \\ 2, korp.5, Pr. Akademika Hlushkova, Kyiv, Ukraine, 03022 \\ ${ }^{3}$ Institute of Biochemistry and Biophysics, Polish Academy of Sciences \\ 5a, Pawinskiego, Warsaw, Poland, 02-106 \\ ${ }^{4}$ NanoBioMedical Centre, Adam Mickiewicz University \\ 85, Umultowska, Poznan, Poland, 61-614 \\ vorobyovannatali_0307@ukr.net
}

\begin{abstract}
AIMP1/p43 protein is a structural component of multisynthetase complex (codosome) in eukaryotes, which reveals both tRNA binding and cytokine activities. Aim. Bacterial expression and purification of isotopically-labeled recombinant AIMP1/p43 protein in E.coli cells for studying its solution structure by multidimensional NMR spectroscopy. Methods. AIMP1/p43 protein was expressed in E. coli BL21(DE3) pLysE cells on M9 minimal medium with $15 \mathrm{~N}$ isotope labeling and purified by metal-chelated chromatography. Heteronuclear 2D 1H-15N NMR experiments were performed in solution at $293 \mathrm{~K}$ on Agilent DDR2 800 NMR spectrometer. Results. The AIMP1/p43 protein was obtained in uniformly $15 \mathrm{~N}$-labeled form as an NMR sample. A high dispersion of resonance signals in the 2D 1H-15N HSQC NMR spectra confirmed the presence of its compact 3D protein structure. The NMR spectrum of AIMP1/p43 demonstrated a high signal-to-noise ratio and sufficient stability to acquire other multidimensional NMR data sets for determination of the structure of AIMP1/p43 protein in solution. Conclusions. The $15 \mathrm{~N}-$ labeled AIMP1/p43 protein was stable for 4-7 days, which makes possible acquiring the critical NMR experimental data for detailed structural analysis in solution. Our data on the initial NMR spectra indicated the presence of some additional signals in comparison with the NMR spectrum of EMAP II which could be assigned to amino acids of the N-terminal $\alpha$-helical fragment of AIMP1/p43.
\end{abstract}

Ke y w o r d s: cytokine, AIMP1/p43, protein expression, isotope labeling, NMR-spectroscopy.

\section{Introduction}

In mammals, nine aminoacyl-tRNA synthetases are associated with three auxiliary proteins AIMP $1 / \mathrm{p} 43$, AIMP2/p38 and AIMP3/p18 (aminoacyl tRNA synthetase interacting with multifunctional proteins, AIMPs) to form a stable multiprotein complex composed of two subcomplexes [1]. One subcomplex is composed of arginyl-tRNA synthetase, glutaminyltRNA synthetase and AIMP1/p43; another subcom- plex includes the rest of the components. These two subcomplexes are connected via AIMP2/p38. The formation of interaction between AIMP $1 / \mathrm{p} 43$ and ArgRS-GlnRS is one of the key stages of assembly of the full complex [2]. The AIMP1/p43 component, which has a potent tRNA binding capacity is associated to the complex via its $\mathrm{N}$-terminal moiety [3].

At the present stage of the development of medicine, the usage of recombinant proteins as therapeutic agents becomes widespread. Protein drugs offer many

(C) 2015 N. V. Vorobyova et al.; Published by the Institute of Molecular Biology and Genetics, NAS of Ukraine on behalf of Biopolymers and Cell. This is an Open Access article distributed under the terms of the Creative Commons Attribution License (http://creativecommons.org/licenses/by/4.0/), which permits unrestricted reuse, distribution, and reproduction in any medium, provided the original work is properly cited 
new therapeutic approaches mainly aimed at the treatment of severe chronic diseases and cancer. The main problem of these drugs is their instability. To overcome this problem in pharmacology, additional chemicals such as cyclodextrins [4] can be used, which as auxiliary agents are capable to reduce the level of aggregation of the protein components, to enhance the resistance to blood proteolytic enzymes and increase their solubility.

The AIMP1/p43 protein and its proteolytic cleavage product EMAP II performs a number of functions associated with the cytokine activity [5-8]. The ability of p43 to induce the TNF synthesis was experimentally demonstrated [9], as well as its regulatory role in the angiogenesis [10], the adhesion regulation of endothelial and immune cells [11], the property of inducing cytokines such as IL-8, MCP-1, MIP-1a, MIP1b, MIP-2a, IL-1b and RANTES [12].

The high-resolution 3D structure of full-length AIMP1/p43 has not been established yet in either monomer or dimer state. The goal of the present work is the optimization of protocols of expression and purification of AIMP1/p43 in Escherichia coli bacteria to achieve maximal quantity of the uniformly ${ }^{15} \mathrm{~N}$ or / and ${ }^{13} \mathrm{C},{ }^{15} \mathrm{~N}$ isotope-labeled recombinant protein. The prepared sample was used to acquire preliminary heteronuclear NMR spectra and to inspect the dispersion of resonances. Additionally, we controlled the experimental conditions (buffer, temperature, $\mathrm{pH}$ ) from the point of view of long-term protein stability in solution, requested to record the multidimensional NMR data sets. This study is an initial step to evaluate the high-resolution 3D AIMP1/ p43 structure using modern techniques recently developed in multidimensional NMR spectroscopy.

\section{Materials and methods}

\section{Recombinant protein expression}

Escherichia coli cells strain BL21 (DE3) pLysE was transformed by plasmid pET28b-p43 (courtesy of Dr. M. Mirande, Laboratoire d'Enzymologie et Biochimie Structurales, CNRS, France).

M9 minimal medium (1 L): $100 \mathrm{ml}$ of $10^{\mathrm{x}} \mathrm{M} 9$ salt; $1 \mathrm{~g}$ of $\left[{ }^{15} \mathrm{~N}\right]-\mathrm{NH}_{3} \mathrm{Cl} ; 10 \mathrm{ml}$ of $100^{\mathrm{x}}$ of trace metal solution; $1 \mathrm{ml}$ of $2 \mathrm{M} \mathrm{MgSO}_{4} ; 100 \mu \mathrm{l} 1 \mathrm{M} \mathrm{CaCl}_{2} ; 2 \mathrm{~g}$ of glucose; $1 \mathrm{ml}$ of $1 \mathrm{mg} / \mathrm{ml}$ biotin; $1 \mathrm{ml}$ of $1 \mathrm{mg} / \mathrm{ml}$ thiamine; $1 \mathrm{ml}$ of $30 \mathrm{mg} / \mathrm{ml}$ kanamycin. Agar (1.5\%) M9 minimal medium was prepared with the addition of 1.5 $\mathrm{g}$ of agar per $100 \mathrm{ml}$ of liquid medium. M9 salts $(1 \mathrm{~L})$ : $60 \mathrm{~g} \mathrm{Na}_{2} \mathrm{HPO}_{4} ; 30 \mathrm{~g} \mathrm{KH}_{2} \mathrm{PO}_{4} ; 5 \mathrm{~g} \mathrm{NaCl}$. Composition $100^{\mathrm{x}}$ trace metal solutions (1 L): $5 \mathrm{~g}$ EDTA; $830 \mathrm{mg}$ $\mathrm{FeCl}_{3} \times 6 \mathrm{H}_{2} \mathrm{O} ; 84 \mathrm{mg} \mathrm{ZnCl} ; 13 \mathrm{mg} \mathrm{CuCl} \times 2 \mathrm{H}_{2} \mathrm{O} ; 13$ $\mathrm{mg} \mathrm{CoCl} \times 6 \mathrm{H}_{2} \mathrm{O} ; 10 \mathrm{mg} \mathrm{H}_{3} \mathrm{BO}_{3} ; 1.6 \mathrm{mg} \mathrm{MnCl}_{2} \times 6$ $\mathrm{H}_{2} \mathrm{O}$. Competent cells of E. coli strain BL21 (DE3) pLysE transformed by plasmid pET28b-p43 and plated on a Petri dish with agar M9 minimal medium.

Recombinant protein AIMP1/p43 was obtained from $400 \mathrm{ml}$ of bacterial suspension on M9 minimal medium with ${ }^{15} \mathrm{NH}_{4} \mathrm{Cl}$ and $30 \mu \mathrm{g} / \mathrm{ml}$ kanamycin. The culture was grown at $37^{\circ} \mathrm{C}$ on a thermostatted shaker (Environmental Shaker Incubator ES-20) to an optical density of $\mathrm{A}_{600}=0.511$ and synthesis of target protein was induced by adding $1 \mathrm{mM}$ IPTG, followed by incubation for $4.0 \mathrm{~h}$ at $30{ }^{\circ} \mathrm{C}$. The cells were harvested by centrifugation at $4000 \mathrm{~g}$ for $20 \mathrm{~min}$ (centrifuge $\mathrm{K}-23$ ) and frozen at $-20^{\circ} \mathrm{C}$ overnight. The frozen cell pellet was suspended in $48 \mathrm{ml}$ of cell lysis buffer (50 $\mathrm{mM}$ sodium phosphate buffer, $\mathrm{pH} 8.0,500 \mathrm{mM} \mathrm{NaCl}$, $10 \mathrm{mM}$ imidazole, $5 \mathrm{mM} \beta$-mercaptoethanol, $5 \mathrm{mM}$ DTT, 5 \% glycerol, 1 mM lysozyme, 1 mM EDTA, 1 $\mathrm{mM}$ PMSF). Ultrasonic lysis of cells was carried out (6 cycles of $20 \mathrm{~s}, 20 \mathrm{~s}$ intervals). The sonicated cells were clarified by centrifugation at $13,000 \mathrm{rpm}$ for 30 min to micro-centrifuge Sigma 1-13.

\section{Affinity chromatography on Ni-NTA-agarose column}

The supernatant was applied to the equilibrated NiNTA-agarose column, washed with $20 \mathrm{ml}$ of wash buffer - $50 \mathrm{mM}$ sodium phosphate buffer, $\mathrm{pH}$ 8.0, $500 \mathrm{mM} \mathrm{NaCl}, 20 \mathrm{mM}$ imidazole, $5 \mathrm{mM} \beta$-mercaptoethanol. The target protein was eluted with $5 \mathrm{ml}$ of elution buffer $-50 \mathrm{mM}$ sodium phosphate buffer, $\mathrm{pH}$ 8.0, $150 \mathrm{mM} \mathrm{NaCl}, 200 \mathrm{mM}$ imidazole, $5 \mathrm{mM} \beta$-mercaptoethanol - and collected in 6 fractions (each one had volume of $1 \mathrm{ml}$ ) stored at $4{ }^{\circ} \mathrm{C}$. Protein concentration was determined by UV absorption and by the method of Bradford [13]. The final concentration of protein was performed on micro concentrators («Millipore», France) to the desired concentration. The 

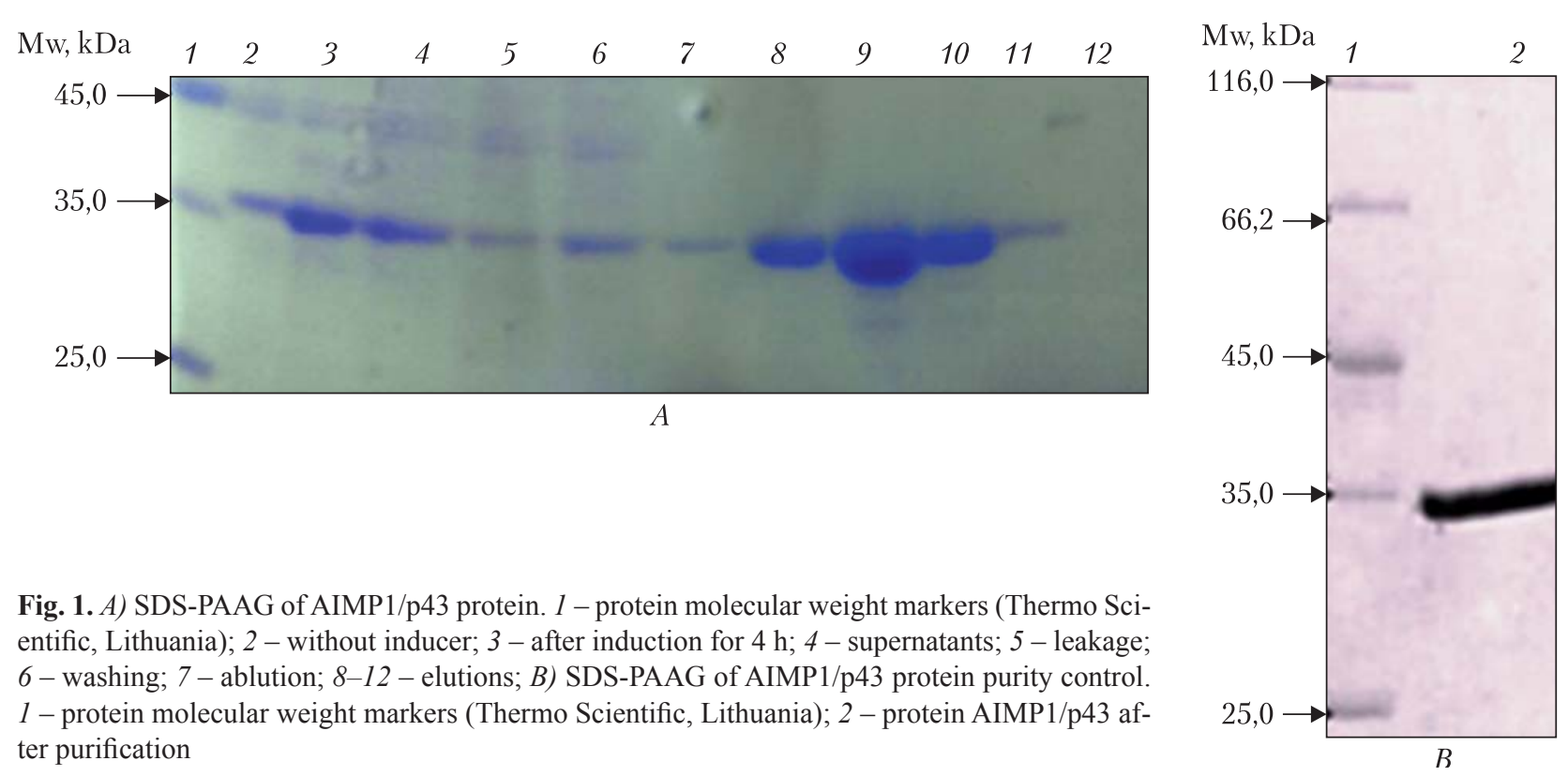

Fig. 1. A) SDS-PAAG of AIMP1/p43 protein. 1 - protein molecular weight markers (Thermo Scientific, Lithuania); 2 - without inducer; 3 - after induction for 4 h; 4 - supernatants; 5 - leakage; 6 - washing; 7 - ablution; 8-12 - elutions; B) SDS-PAAG of AIMP1/p43 protein purity control. 1 - protein molecular weight markers (Thermo Scientific, Lithuania); 2 - protein AIMP1/p43 after purification

purity of the obtained protein p43 was checked by electrophoresis under denaturing conditions in the presence of sodium dodecyl sulfate $12 \%$ polyacrylamide gel for Lemmli [14] using a mixture of marker proteins («Thermo Scientific», Lithuania).

\section{Analysis of physical and chemical properties}

Physico-chemical properties of recombinant AIMP1/ p43 were analyzed by ProtParam (http://expasy.org/ tools/protparam.html): molecular weight of 35417.7 $\mathrm{Da}$; isoelectric point $\mathrm{pI}=8.42$. Predicted molar extinction coefficient at $280 \mathrm{~nm}$ is $10220 \mathrm{M}^{-1} \mathrm{~cm}^{-1}$; optical absorption of $0.1 \%$ solution is 0.289 .

\section{Spectrophotometric determination of protein concentration}

UV-absorption spectra of recombinant AIMP1/p43 were measured using a spectrophotometer BioMate-5 («Termo Scientific», UK) in quartz cuvettes with an optical path length of $1 \mathrm{~cm}$. Protein concentration was determined spectrophotometrically using absorption at $280 \mathrm{~nm}\left(\mathrm{~A}_{280}\right)$ based on extinction coefficient $\mathrm{e}_{\mathrm{AIMP} 1 / \mathrm{p} 43}=10220 \mathrm{M}^{-1} \mathrm{~cm}^{-1}$.

\section{NMR spectroscopy}

All NMR experiments were carried out at $20{ }^{\circ} \mathrm{C}$ in the NMR spectrometer Agilent DDR2 $800\left({ }^{1} \mathrm{H}\right.$ reso- nance frequency is $800 \mathrm{MHz}$ ), equipped with four frequency channels, ${ }^{1} \mathrm{H} /{ }^{13} \mathrm{C} /{ }^{15} \mathrm{~N}$ probehead with inverse detection and z-gradient unit. The ${ }^{1} \mathrm{H}$ and ${ }^{15} \mathrm{~N}$ dimensions were referenced in respect to external sodium 2,2-dimethyl-2-silapentane-5-sulfonat(DSS) using previously described procedure [20]. All NMR spectra were processed using NMRPipe [15] and analyzed with Sparky [16] software.

\section{Results and Discussion}

Determination of the spatial structure of the AIMP1/ p43 protein in solution at physiological conditions is an urgent task. At the moment only C-terminal fragment of 3D structure (EMAP II domain) has been determined. According to our bioinformatics analysis, the AIMP1/p43 protein contains a long structurally disordered fragment in the middle of polypeptide (unpublished results). In such case, NMR spectroscopy is the only method which allows determining the $3 \mathrm{D}$ structure of proteins in solution and establishing the correlation between crystal and solution structures. It should be noted that the NMR spectroscopy is the only method for structure determination of intrinsically disordered proteins.

Usually, NMR spectroscopy determination of the protein $3 \mathrm{D}$ structure in solution includes the isotope labeling procedures in the following combina- 


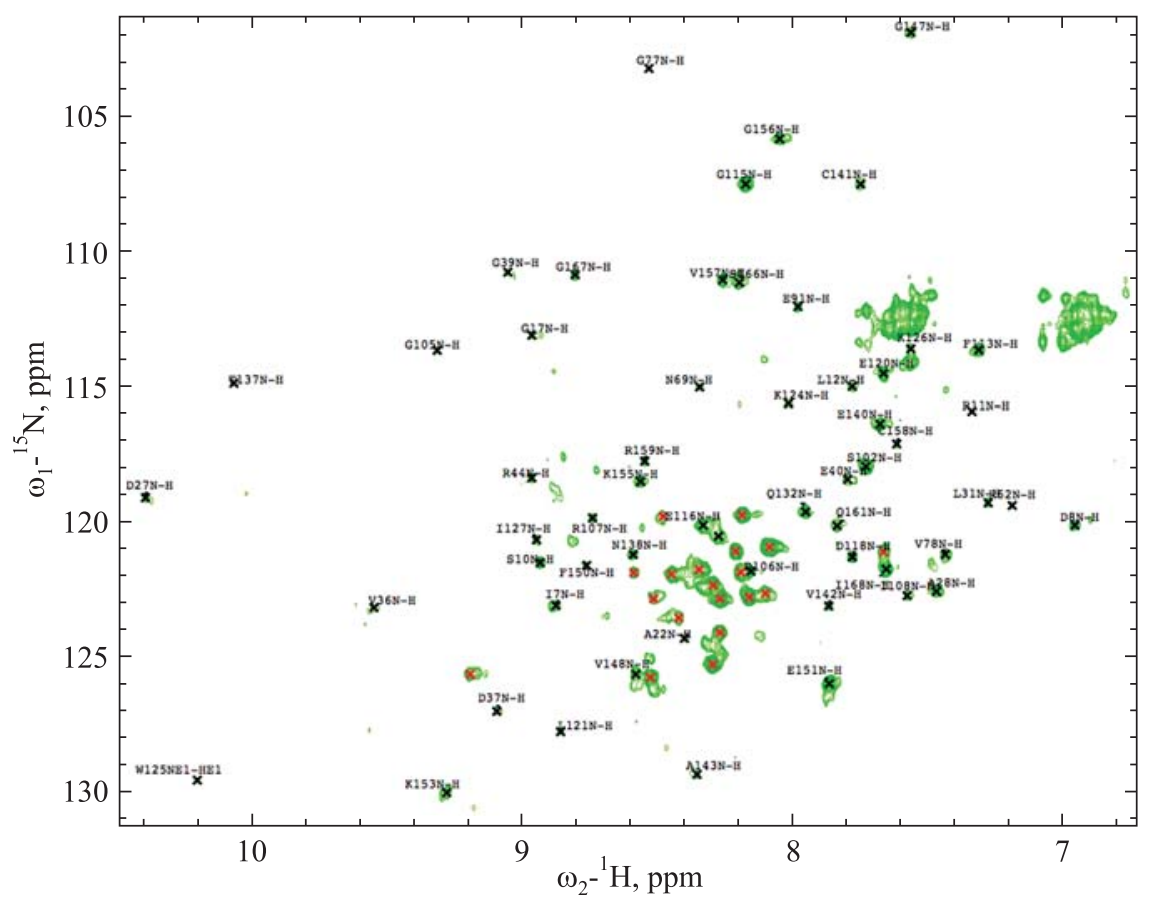

Fig. 2. Two-dimensional NMR spectrum of ${ }^{1} \mathrm{H} /{ }^{15} \mathrm{~N}$ HSQC (heteronuclear single quantum correlation experiment) AIMP1/p43 recombinant protein in solution, which records the signals of amide groups of the polypeptide core protein, recorded at a frequency of $800 \mathrm{MHz}$ by NMR spectrometer at Agilent DDR2 800. Assigned signals belongs to the C-terminal part of protein (EMAP II), unassigned (marked by red) - N-terminal part

tions: ${ }^{15} \mathrm{~N},{ }^{15} \mathrm{~N} /{ }^{13} \mathrm{C}$ double labeling and ${ }^{2} \mathrm{H} /{ }^{13} \mathrm{C} /{ }^{15} \mathrm{~N}$ triple labeling. At the first step, a studied protein is labeled with ${ }^{15} \mathrm{~N}$ isotope in order to verify the feasibility of the next stages of the research. To determine the solution structure, we performed the bacterial expression and ${ }^{15} \mathrm{~N}$ isotope labeling of the recombinant AIMP1/p43 polypeptide according to the technique described earlier [17]. The optimized protocol of the synthesis and purification procedures finally yields about $8 \mathrm{mg}$ of recombinant uniformly ${ }^{15} \mathrm{~N}$-labeled AIMP1/p43 protein from $1 \mathrm{~L}$ of cell culture of $E$. coli, which is economically viable to apply the method of isotopic labeling. In this case, the protein is sufficiently soluble and relatively for 4-7 days stable, as determined from the NMR spectra. An analysis of the AIMP1/p43 protein by gel electrophoresis under denaturing conditions showed its high homogeneity and purity (at least 95 \%) (Fig. 1).

A significant yield of the protein indicates the absence of such problems as the protein expression toxicity for $E$. coli cells, instability, improper processing and inefficient translation of the protein. The obtaining of the AIMP1/p43 protein preparations at concentrations of $0.3-0.5 \mathrm{mM}$ is well maintained by the intensive dialysis against $50 \mathrm{mM}$ sodium phosphate buffer, $250 \mathrm{mM} \mathrm{NaCl}, 1 \mathrm{mM}$ DDT at $\mathrm{pH} 8.0$ which was performed for the removal of imidazole and organic contaminants.

Two-dimensional ${ }^{1} \mathrm{H}-{ }^{15} \mathrm{~N}$ HSQC spectra of the ${ }^{15} \mathrm{~N}$ labeled AIMP1/p43 protein demonstrate good dispersion of resonances coming from amide groups of the polypeptide chain (Figure 2). A comparison with the previously recorded data for the EMAPII protein which constitutes the C-terminal module of AIMP1/ p43 exhibited good correlation. This strongly supports an idea that the 3D structure of the C-terminal part of the AIMP1/p43 protein is very similar to the previously determined 3D structure of the EMAP II protein [18]. The presented NMR data for the AIMP1/p43 protein indicated also the presence of some additional signals in comparison to the EMAP 
Bacterial expression and isotope labeling of AIMP1/p43 codosome protein

II spectrum (Fig. 2). The additional signals detected are well separated from the signals coming from the C-terminal part, are characterized by high amplitude and small linewidth, and more probably correspond to the amino acids located in the long unstructured part of the AIMP1/p43 structure. In this regard it is important to note that our prediction of the AIMP $1 / \mathrm{p} 43 \mathrm{sec}-$ ondary structure suggested the presence of $\alpha$-helical fragment at the $\mathrm{N}$-terminal part connected with the $\mathrm{C}$ terminal domain by the long mobile loop (unpublished data). Additionally, these data correlate well with the results of X-ray diffraction studies of the ArgRS-G1nRS-AIMP1 complex structure [2]. However, so far these additional NMR signals have not been exactly assigned to the specific amino acid residues of AIMP1/ p43 and will be the subject of our further research.

Additionally, NMR spectroscopy may also be useful to explore the interactions of the protein with different ligands and to determine the structure of these complexes. It is known that AIMP $1 / \mathrm{p} 43$ revealed some cytokine properties, which may be modulated in some nanocomposite complexes. In this regard, we focused on creating some nanocomposite systems of AIMP1/p43 for further implementation as novel potential anticancer drugs. NMR spectroscopy will be very useful to determine the structure of different nanocomposite complexes of AIMP1/p43 for biomedical application.

The obtained data confirm the existence of a stable NMR spatial structure of the $\mathrm{p} 43$ protein in aqueous solution and the possible formation of $\alpha$-helical fragments in the N-terminal part of the polypeptide. The results suggest the possibility of determining the AIMP1/p43 protein $3 \mathrm{D}$ structure in solution by multi-dimensional NMR spectroscopy.

\section{Acknowledment}

Authors express gratitude to Professor Mark Mirande (Laboratoire d'Enzymologie et Biochimie Structurales, CNRS, France) for kindly provided plasmid pET28b-p43.

\section{Funding}

This work was partially supported by Polish National Centre for Research and Development under re- search grant number 178479 (contract number PBS1/ A9/ 13/2012) (for IZ).

\section{REFERENCES}

1. Wolfe CL, Warrington JA, Davis S, Green S, Norcum MT. Isolation and characterization of human nuclear and cytosolic multisynthetase complexes and the intracellular distribution of p43/EMAPII. Protein Sci. 2003;12(10):2282-90.

2. Fu Y, Kim Y, Jin KS, Kim HS, Kim JH, Wang D, Park M, Jo CH, Kwon NH, Kim D, Kim MH, Jeon YH, Hwang KY, Kim $S$, Cho $Y$. Structure of the ArgRS-GlnRS-AIMP1 complex and its implications for mammalian translation. Proc Natl Acad Sci U S A. 2014;111(42):15084-9.

3. Guigou L, Shalak V, Mirande M. The tRNA-interacting factor $\mathrm{p} 43$ associates with mammalian arginyl-tRNA synthetase but does not modify its tRNA aminoacylation properties. Biochemistry. 2004;43(15):4592-600.

4. Girek T, Goszczyński T, Girek B, Ciesielski W, Boratyński J, Rychter P. $\beta$-Cyclodextrin/protein conjugates as a innovative drug systems: synthesis and MS investigation. $J$ Incl Phenom Macrocycl Chem. 2012;75(3-4):293-6.

5. Quevillon S, Mirande $M$. The p18 component of the multisynthetase complex shares a protein motif with the beta and gamma subunits of eukaryotic elongation factor 1. FEBS Lett. 1996;395(1):63-7.

6. Reznikov AG, Chaykovskaya LV, Polyakova LI, Kornelyuk AI. Antitumor effect of endothelial monocyte-activating polypeptide-II on human prostate adenocarcinoma in mouse xenograft model. Exp Oncol. 2007;29(4):267-71.

7. Reznikov AG, Chaykovskaya LV, Polyakova LI, Kornelyuk AI, Grygorenko VN. Cooperative antitumor effect of endothelial-monocyte activating polypeptide II and flutamide on human prostate cancer xenografts. Exp Oncol. 2011;33(4): 231-4.

8. Ivakhno SS, Kornelyuk AI. Cytokine-like activities of some aminoacyl-tRNA synthetases and auxiliary p43 cofactor of aminoacylation reaction and their role in oncogenesis. Exp Oncol. 2004;26(4):250-5.

9. Park H, Park SG, Kim J, Ko YG, Kim S. Signaling pathways for TNF production induced by human aminoacyl-tRNA synthetase-associating factor, p43. Cytokine. 2002;20(4):148-53.

10. Park SG, Kang YS, Ahn YH, Lee SH, Kim KR, Kim KW, Koh $G Y$, Ko YG, Kim S. Dose-dependent biphasic activity of tRNA synthetase-associating factor, p43, in angiogenesis. J Biol Chem. 2002;277(47):45243-8.

11. Park H, Park SG, Lee JW, Kim T, Kim G, Ko YG, Kim S. Monocyte cell adhesion induced by a human aminoacyl-tRNA synthetase-associated factor, $\mathrm{p} 43$ : identification of the related adhesion molecules and signal pathways. J Leukoc Biol. 2002;71(2):223-30.

12. Ko YG, Park H, Kim T, Lee JW, Park SG, Seol W, Kim JE, Lee WH, Kim SH, Park JE, Kim S. A cofactor of tRNA synthetase, p43, is secreted to up-regulate proinflammatory genes. J Biol Chem. 2001;276(25):23028-33. 
13. Bradford MM. A rapid and sensitive method for the quantitation of microgram quantities of protein utilizing the principle of protein-dye binding. Anal Biochem. 1976;72:248-54.

14. Laemmli UK. Cleavage of structural proteins during the assembly of the head of bacteriophage T4. Nature. 1970;227 (5259):680-5.

15. Delaglio F, Grzesiek S, Vuister GW, Zhu G, Pfeifer J, Bax $A$. NMRPipe: a multidimensional spectral processing system based on UNIX pipes. J Biomol NMR. 1995;6(3):27793.

16. Goddard TD, Kneller DG. SPARKY 3. San Francisco: Univ. of California. 2008.

17. Lozhko DM, Zhukov IY, Kornelyuk AI. Bacterial expression and $13 \mathrm{C} / 15 \mathrm{~N}$ isotopic labeling of EMA PII cytokine for structural studies by NMR spectroscopy. Biopolym Cell. 2011;27 (4):273-8.

18. Lozhko D, Stanek J, Kazimierczuk K, Zawadzka-Kazimierczuk A, Kozminski W, Zhukov I, Kornelyuk A. (1)H, (13)C, and (15)N chemical shifts assignments for human endothelial monocyte-activating polypeptide EMAP II. Biomol NMR Assign. 2013;7(1):25-9.

\section{Бактеріальна експресія та ізотопне мічення білка AIMP1/p43 кодосоми для структурних досліджень муль- тивимірною ЯМР спектроскопією}

Н. В. Воробйова, Д. М. Ложко, І. Ю. Жуков, О. І. Корнелюк AIMP1/p43 - структурний компонент мультисинтетазного комплексу (кодосома) евкаріот, який проявляє тРНК зв'язуючу та цитокінову активності. Мета. Провести бактеріальну експресію та очистку ізотопно-міченого рекомбінантнога білка AIMP1/p43 в клітинах E. coli для вивчення його просторової структури методами мультивимірної ЯМР спектроскопії. Методи. AIMP1/p43 експресовано в клітинах E. coli BL21 (DE3) pLysE на мінімальному середовищі M9 3 міченням ізотопом ${ }^{15} \mathrm{~N}$ та очищено за допомогою метал-хелатуючої хроматографії. Гетероядерні двомірні ${ }^{1} \mathrm{H}-{ }^{15} \mathrm{~N}$ ЯМР експерименти проводилися в розчині при температурі $293 \mathrm{~K}$ на ЯMP спектрометрі Agilent DDR2 800. Результати. Білок AIMP1/p43 отримано в ${ }^{15} \mathrm{~N}$-міченій формі в якості ЯМР зразка. Висока дисперсія сигналів у двомірних ЯМР спектрах ${ }^{1} \mathrm{H}-15 \mathrm{~N}$ HSQC підтверджує наявність компактної тривимірної структури білка. ЯМР спектр AIMP1/p43 виявляє значне співвідношення сигнал-шум та достатню стабільність, щоб застосувати інші багатовимірні ЯМР експерименти для визначення структури AIMP1/p43 білка у розчині. Висновки. ${ }^{15} \mathrm{~N}$-мічений білок AIMP1/p43 зберігає стабільність протягом 4-7 днів, що дає можливість подальшого отримання важли- вих ЯМР експериментів для проведення детального структурного аналізу білка у розчині. Наші дані первинного аналізу спектрів ЯМР вказують на присутність деяких додаткових сигналів у порівнянні зі спектрами ЯМР EMAP II, які можуть бути віднесені до амінокислот N-кінцевого $\alpha$-спірального фрагмента AIMP1/p43.

Кл юч о в і с л о в а: цитокіни, AIMP1/p43, експресія білка, ізотопне мічення, ЯМР спектроскопія.

\section{Бактериальная экспрессия и изотопное мечение белка AIMP1/p43 кодосомы для структурных исследований мультимерной ЯМР спектроскопей}

Н. В. Воробьева, Д. Н. Ложко, И. Ю. Жуков, А. И. Корнелюк Белок AIMP1/p43 является структурным компонентом мультисинтетазного комплекса (кодосома) эукариот, который проявляет тРНК связующую и цитокиновую активности. Цель. Провести бактериальную экспрессию и очистку изотопно-меченого рекомбинантного белка AIMP $1 / \mathrm{p} 43$ в клетках E. coli для изучения его пространственной структуры методами мультимерной ЯМР спектроскопии. Методы. AIMP1/p43 экспрессировали в клетках E. coli BL21 (DE3) pLysE на минимальной среде M9 с мечением изотопом ${ }^{15} \mathrm{~N}$ и очистили с помощью металл-хелатирующий хроматографии. Гетероядерные двумерные ${ }^{1} \mathrm{H}-{ }^{15} \mathrm{~N}$ ЯМР эксперименты проводились в растворе при температуре 293 К на ЯМР спектрометре Agilent DDR2 800. Результаты. Белок AIMP1/ p43 получен в ${ }^{15} \mathrm{~N}$-меченной форме в качестве ЯМР образца. Высокая дисперсия сигналов в двумерных ЯМР спектрах ${ }^{1} \mathrm{H}-{ }^{15} \mathrm{~N}$ HSQC подтверждает наличие компактной трехмерной структуры белка. ЯМР спектр AIMP1/p43 показывает значительное соотношение сигнал-шум и достаточную стабильность, чтобы применить другие многомерные ЯМР эксперименты для определения структуры AIMP1/p43 белка в растворе. Выводы. ${ }^{15} \mathrm{~N}$-меченый белок AIMP $1 / \mathrm{p} 43$ coxраняет стабильность в течение 4-7 дней, что дает возможность дальнейшего получения важных ЯМР экспериментов для проведения детального структурного анализа белка в растворе. Наши данные первичного анализа спектров ЯМР указывают на присутствие некоторых дополнительных сигналов в сравнении со спектрами ЯМР ЕMAР II, которые могут быть отнесены к аминокислотам N-концевого $\alpha$-спирального фрагмента AIMP1/p43.

К л юч е в ы е с л о в а: цитокины, AIMP1/p43, экспрессия белка, изотопное мечение, ЯМР спектроскопия.

Received 01.11.2014 